\title{
Nutrition and growth in newly established plantations of Eucalyptus globulus in northwestern Spain
}

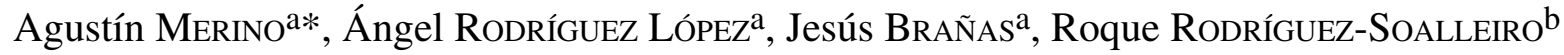 \\ a Department of Soil Science and Agricultural Chemistry, Escuela Politécnica Superior, Universidad de Santiago de Compostela, 27002 Lugo, Spain \\ b Department of Forest Production, Escuela Politécnica Superior, Universidad de Santiago de Compostela, 27002 Lugo, Spain
}

(Received 15 November 2002; accepted 22 February 2003)

\begin{abstract}
The growth and nutritional status of newly established Eucalyptus globulus plantations, located in NW Spain, were studied in relation to soil properties and site preparation techniques. Most of the plantations are growing on chemically poorly fertile soils of intermediate depth. Despite being fertilized at establishment, most of the plantations showed low foliar levels of $\mathrm{P}$ and $\mathrm{Ca}$, and some showed deficiencies of $\mathrm{Mg}$ and $\mathrm{K}$. Growth depended mainly on the altitude, length of the drought period and on concentrations of Ca in soils. Productivity is reflected by the concentrations of $\mathrm{Ca}$ in leaves. Preparation of the soil by windrowing reduced levels of $\mathrm{Ca}, \mathrm{Mg}$ and $\mathrm{P}$ in the soil, negatively affecting nutrition and growth and causing an increase in tree mortality. The results suggest subsoiling to be the most suitable site preparation technique for shallow soils, and also indicate the need for repeated fertilization and the adoption of silviculture management practices that enhance the natural turnover of nutrients.
\end{abstract}

Eucalyptus globulus / forest nutrition / forest soils / silviculture / forest growth

Résumé - Nutrition et croissance dans les nouvelles plantations d'Eucalyptus globulus du nord ouest de l'Espagne. La croissance et l'état nutritionnel des plantations d'Eucalyptus globulus du nord-ouest de l'Espagne ont été étudiés en fonction des caractéristiques édaphiques et des techniques de préparation du site. La plupart des plantations sont installées sur des sols pauvres de profondeur moyenne. Bien que fertilisées à la plantation, la plupart des plantations révèlent des concentrations foliaires limites en $\mathrm{P}$ et $\mathrm{Ca}$, et certaines révèlent des carences en $\mathrm{Mg}$ et $\mathrm{K}$. La croissance dépend principalement de l'altitude, de la durée de la période sèche et aussi de la concentration de Ca au sol. La concentration de $\mathrm{Ca}$ en feuilles est très représentative de la croissance. L'extraction de litière et les rémanents d'exploitation lors de la préparation du site, réduisent la teneur en $\mathrm{Ca}, \mathrm{Mg}$ et $\mathrm{P}$ du sol, affectant de manière négative la nutrition et la croissance, et aboutissant à une hausse de la mortalité Ces résultats suggèrent l'idoneité du subsolage comme méthode de préparation du site, la nécessité de fertiliser plusieurs fois et d'adopter une sylviculture qui favorise le renouvellement naturel des nutriments.

Eucalyptus globulus / nutrition forestière / sols forestiers / silviculture / croissance forestière

\section{INTRODUCTION}

An increased demand for wood has led to rapid expansion of plantations of fast-growing forest species in some regions of Spain and Portugal, where more than 1000000 ha of land have been planted with such species in the last decades. In northwestern Spain, Eucalyptus globulus is the most widespread species in forest plantations and makes up $20 \%$ of all the woodland area, either in monocultures or in mixed stands with Pinus pinaster [16]. The total standing volume is about $35 \mathrm{mil}-$ lion $\mathrm{m}^{3}$ and the wood produced is mainly used for wood pulp (53\%), woodchip (36\%) and saw timber (11\%) [7].

Most eucalypts are planted by forestry companies on existing forest soils, in areas with a range of limitations for forest productivity, although there is an increasing incidence of land- owners establishing eucalypt plantations on abandoned agricultural soils, which are highly productive. The plantations are managed in short rotations, usually of $12-15$ years. The management is usually intensive and includes clearing of brushwood, mechanical site preparation and plantation of containerized seedlings. In many stands, fertilization is carried out at establishment. Genetically improved stock is not yet available for general use in Spain. The most widely employed site preparation technique is deep tillage, whereas in the steepest areas, preparation of planting holes is preferred. On low slopes, discharrowing or mounding may also be used. To facilitate access for planting and to speed up decomposition, chopping rollers are often used to break up the logging residues. A very intensive technique consisting of pushing the logging residues and humus layer to the side of the site (windrowing) is sometimes

\footnotetext{
* Corresponding author: amerino@lugo.usc.es
} 
carried out. Stands are frequently regenerated by coppicing and three coppice crops can usually be obtained before loss of vigour. Eucalypt production differs according to the soil conditions (mainly in relation to drainage, soil depth, chemical fertility) [9] and also to the type of silvicultural management, such as fertilization at establishment and vegetation control [26]. Productivity ranges from 10 to $40 \mathrm{~m}^{3} \mathrm{ha}^{-1}$ year-1, with an average value of $20 \mathrm{~m}^{3} \mathrm{ha}^{-1}$ year ${ }^{-1}$.

Forest soils in northern Spain are strongly acidic and contain low levels of extractable $\mathrm{Ca}, \mathrm{Mg}, \mathrm{K}$ and $\mathrm{P}$ [5, 17, 28, 36]. The low reserves of elements in forest soils are attributed to high leaching, slow weathering of the minerals in the parent material $[14,37]$ and also to their high capacity for fixing $\mathrm{P}$ [24]. The success of Eucalyptus globulus in northern Spain is partly due to the favourable climatic conditions, but also to its tolerance to acid soils, low requirements of $\mathrm{P}, \mathrm{Ca}$ and $\mathrm{Mg}$ and preferential absorption of $\mathrm{NH}_{4}^{+}$in relation to $\mathrm{NO}_{3}^{-}[2,10]$. However, analyses carried out in previous studies [9, 18] revealed low foliar levels $\mathrm{P}, \mathrm{Ca}$ and $\mathrm{Mg}$, as well as large amounts of nutrients exported from the site during harvesting compared with the nutrient storage of the soils, especially in shallow and stony soils with low soil reserves [9]. Positive responses have also been found after incorporation of the logging residues into the soil [31] or mechanical site preparation consisting of vegetation control and subsoiling [50].

In addition to the nutritional limitations associated with these factors, eucalypt plantations have been seriously damaged in recent years by the fungus Micosphaerella spp., which destroys the leaves of young trees. Plagues of Gonipterus scutellatus, a beetle that defoliates the trees, can also greatly reduce productivity in eucalyptus plantations, especially those located at higher altitudes [39].

The aim of the present study was to assess the growth and nutritional status in newly established plantations on existing forest soils (plantations on abandoned agricultural soils were not investigated in this study). These aspects were evaluated in a number of plantations covering a range of soil and climatic conditions and site preparation techniques. The information obtained should help to better understand the factors affecting growth of eucalypts as well as to predict growth rates and to plan strategies to alleviate the problems detected.

\section{MATERIALS AND METHODS}

\subsection{Characteristics of the plantations}

The study was carried out in Galicia (NW Spain), the region of Spain with the largest surface area of eucalypt plantations. A total of 44 Eucalyptus globulus plantations of between 2 and 6 years old were selected. The plantations chosen were managed by forestry companies in the region and all were established on existing forest soils, using a local source of seeds as genetic stock.

Fieldwork was carried out in March and April 2000. At each plot the following information was recorded: general data (age, slope height), soil data (drainage, depth, superficial stoniness, parent material) and silvicultural management data (site preparation, stocking density, fertilization). Some of the properties of the stands are given in Table I. The average altitude of the plots studied was $382 \mathrm{~m}$ and the average slope, $23 \%$. The average density of trees in the plantations was 1330 trees ha ${ }^{-1}$. The choice of plots included a vari-
Table I. General characteristics of soils in the Eucalyptus globulus plantations studied.

\begin{tabular}{|c|c|c|c|}
\hline & Mean & Range & Median \\
\hline Altitude $(\mathrm{m})$ & 382 & $70-580$ & 420 \\
\hline Slope $(\%)$ & 23.3 & $1-70$ & 24 \\
\hline Stand age (year) & 4.35 & $2-6$ & 4 \\
\hline Stocking (stems ha-1) & 1329 & 900-1975 & 1350 \\
\hline
\end{tabular}

ety of the most commonly occurring parent materials i.e. schist/slates (12 plots), granitic rocks (24) and quartzite (8 plots).

The site preparation techniques were as follows: pitting (preparation of planting holes without any further mechanical preparation, 4 plots), windrowing (the logging residues and humus layer are pushed to the side of the site) followed by deep tillage (subsoiling with a $80 \mathrm{~cm}$ long ripper powered by a crawler tractor, 13 plots), down-slope deep tillage (17 plots) and preparation of $3 \mathrm{~m}$ wide terraces to be planted ( 8 plots). Before establishment the ground was cleared of brushwood (using chopping rollers) to control growth of understory vegetation. Some of the plantations (25) were fertilized at establishment with approximately $100 \mathrm{~g}$ of NPK type fertilizer per plant.

\subsection{Climatic characteristics and soil properties}

The climate of the northern and northwestern areas of the region is characterized by mild temperatures (annual average temperature $12^{\circ} \mathrm{C}$ ) and a slight hydric deficit (average annual rainfall, $1700 \mathrm{~mm}$; average annual PET, $700 \mathrm{~mm}$; water deficit, $40 \mathrm{~mm}$ ). Temperatures in the southern part of the region are somewhat higher (average annual temperature $14^{\circ} \mathrm{C}$ ), and the water deficit is also larger (average annual rainfall, $1600 \mathrm{~mm}$; average annual PET: $810 \mathrm{~mm}$; water deficit: $141 \mathrm{~mm}$ ).

The general properties of the soils in the region have previously been reported [4, 17, 28, 36, 49]. In summary, the forest soils in the region are characterized by being shallow or of moderate depth, strongly acidic, containing a high proportion of coarse fragments, and with high organic matter and low nutrient contents. They are highly weathered and as a consequence, also show an abundance of low charge minerals (mainly mica and kaolinite), and a low eCEC. The texture is loamy and, in the case of soils developed on granite, sandy.

\subsection{Sampling and analysis of soils and plants}

In each of the plantations, tree measurement and leaf and soil sampling were carried out within a representative subplot, measuring $20 \times 20 \mathrm{~m}$. The heights and diameters of all trees within the subplot were measured. For soil sampling, three pits of $20 \mathrm{~cm}$ depth were dug in each subplot. The samples from each horizon collected in the three pits were mixed together to form a single bulked sample.

Soil samples were air-dried and sieved with a $2 \mathrm{~mm}$ screen before analysis. The $\mathrm{pH}$ was measured in $\mathrm{H}_{2} \mathrm{O}$ and $0.1 \mathrm{M} \mathrm{KCl}$ (soil: solution ratio $1: 2.5$ ) with a glass electrode. Total $\mathrm{C}, \mathrm{N}$ and $\mathrm{S}$ were analyzed with a LECO Elemental Analyzer. Organic matter was calculated as the amount of $\mathrm{C}$ measured, multiplied by 1.72. Available cations (P, $\mathrm{K}, \mathrm{Ca}, \mathrm{Mg}, \mathrm{Mn}, \mathrm{Fe}, \mathrm{Cd}, \mathrm{Cr}, \mathrm{Cu}, \mathrm{Ni}$ and $\mathrm{Pb}$ ) were extracted using the Mehlich 3 procedure [42]. The amounts of $\mathrm{Ca}, \mathrm{Mg}$ and $\mathrm{K}$ extracted by this method are comparable to those obtained by the ammonium acetate method, whereas the amounts of microelements are similar to those obtained by DTPA extraction. Phosphorus was determined by the ascorbic acid method, whereas the other elements were analyzed by atomic absorption spectrophotometry. 
Table II. Distribution of the soil preparation techniques within the types of parent materials.

\begin{tabular}{lccc}
\hline & Quartzite & Schists & Granites \\
\hline Pitting & & 1 & 3 \\
Windrowing & 7 & 3 & 10 \\
Subsoiling & 1 & 1 & 6 \\
Terracing & 1 & 6 \\
\hline
\end{tabular}

Undamaged, full-sized leaves of the current season's growth were sampled in spring from the upper third of the unshaded crowns of all trees (minimum 30) in the subplot. Two sets of samples were made with the material collected and each treated separately in the laboratory. The samples were oven-dried $\left(65^{\circ} \mathrm{C}\right)$ to a constant weight, milled $(0.25 \mathrm{~mm})$ and extracted with $\mathrm{H}_{2} \mathrm{SO}_{4} / \mathrm{H}_{2} \mathrm{O}_{2}$ [32]. Levels of $\mathrm{K}$, $\mathrm{Ca}, \mathrm{Mg}, \mathrm{Mn}, \mathrm{Fe}, \mathrm{Cd}, \mathrm{Cr}, \mathrm{Cu}, \mathrm{Ni}$ and $\mathrm{Zn}$ in the leaf extracts were analyzed by atomic absorption spectrophotometry, whereas $\mathrm{P}$ was determined photometrically. Nitrogen and $\mathrm{S}$ in needles were analyzed in solid milled material using a LECO analyzer. Evaluation of the nutritional status of the trees was made on the basis of the levels of nutrients in leaves and soils.

The available water holding capacity of the soils was calculated following the empirical method developed by Martínez Cortizas [40], in which organic matter content and particle size distribution data are used. The period of drought was estimated using the method outlined by Díaz-Fierros and Gil Sotres [17], which takes into account the water deficit and the water reserve.

\subsection{Evaluation of tree growth and nutritional status}

The age and dominant height data were used to calculate the site index (SI) for each plantation. The site index was calculated from the height growth curves for NW Spain [21], which are based on the polymorphic model of Bailey and Clutter [3]:

$$
\text { Ln } H_{0}=a+b_{i} t^{-c}
$$

where $H_{0}$ is the stand dominant height, $t$ is the age, $a$ and $c$ are fixed parameters and $b_{i}$ is a parameter that depends on the site index (SI). This parameter is defined as the dominant height at a reference age of 10 years, so that reliable predictions were assumed for the range of ages in the plots. The range of SI in the overall area of plantations in the region is 15 to $27 \mathrm{~m}$.

The average annual increment in diameter (AID) was calculated as the average diameter at breast height divided by age. The AID was used as an additional measure of the plantation productivity and was expected to remain stable with age for the narrow range of plantation ages ( 2 to 6 years) in the present study. Tree mortality was also calculated for all plots and used to reflect stand productivity.

\subsection{Statistical analysis}

The effects of site preparation technique and type of soil on the growth and nutrient status of soils and plants were analyzed by analysis of variance. The distribution of soil preparation techniques within the parent materials is considered to be random (Tab. II). Therefore, an unbalanced design with two crossed factors of three and two levels was considered, and a general linear model was used for the analysis, using the GLM procedure of the SAS statistical package [52]. The dependent variables were SI, AID and tree mortality, as well as foliar and soil concentrations of nutrients.

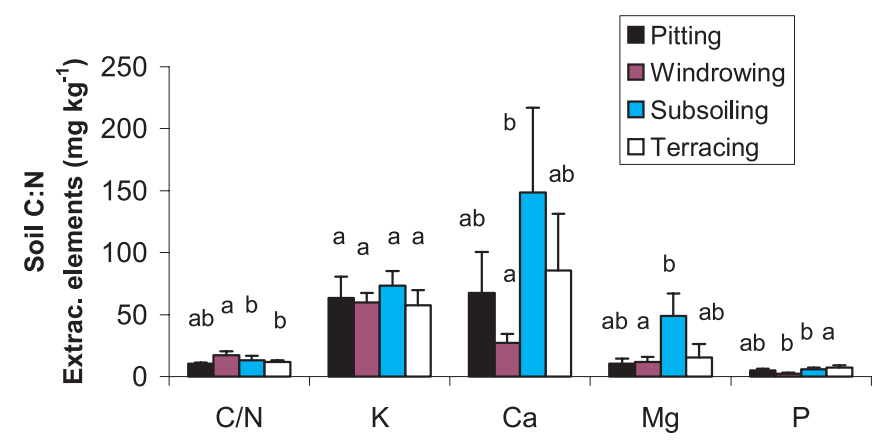

Figure 1. Ratio of $\mathrm{C}: \mathrm{N}$ and concentrations of soil extractable nutrients $\left(\mathrm{mg} \mathrm{kg}^{-1}\right)$ in relation to the site preparation techniques used in newly established Eucalyptus globulus plantations in NW Spain. Significantly different means are indicated by different letters, a > $\mathrm{b}>\mathrm{c}(P<0.05)$.

The relationships among growth indices (site index and annual increment of diameter), soil parameters and foliar levels of nutrients were analyzed by Pearson's correlation, stepwise linear and quadratic regression analyses.

\section{RESULTS}

\subsection{Soil properties in relation to parent material and site preparation technique}

The characteristics of the soils analyzed, grouped by parent material or site preparation technique, are summarised in Table III and Figure 1, respectively. In many of the stands the soil was shallow - less than $40 \mathrm{~cm}$ deep in 20 plots and less than $25 \mathrm{~cm}$ deep in 12 plots - and the soil was deeper than $60 \mathrm{~cm}$ in only 3 plots. In $70 \%$ of the plots, the proportion of the soil consisting of coarse fragments was more than $50 \%$. The water holding capacity was lower in the soils derived from granitic rocks; this was the only statistically significant effect of parent material on soil properties. In 11 plots, in which the soil was shallow, stony and/or sandy, the water reserve was less than $50 \mathrm{~mm}$, which is considered to be low. Despite the low water reserves, significant periods of drought, of up to two months, only occur in the south of the region, where rainfall is lower.

All of the soils studied were highly acidic. Most had $\mathrm{pH}_{\mathrm{KCl}}$ values below 4.0, in both surface and subsurface horizons. Although soils on quartzite tend to be more acidic, no significant differences in $\mathrm{pH}$ in relation to parent material were revealed by analysis of variance. As with most forest soils in the region, the soils were rich in organic matter and contained high levels of total $\mathrm{N}$ and $\mathrm{S}$. In $80 \%$ of the plantations, the C:N ratio in the surface horizon was less than 20 , indicating an adequate rate of decomposition and mineralization of the organic matter. Comparison of the different site preparation techniques showed that the $\mathrm{C}: \mathrm{N}$ ratios in the windrowed soils (where logging residues were removed) were slightly higher than in other soils $(P<0.05$, Fig. 1$)$, which can be attributed to the remobilization of large amounts of $\mathrm{N}$. All of the soils under study contained very low levels of available $\mathrm{P}\left(<10 \mathrm{mg} \mathrm{kg}^{-1}\right)$. The parent material did not influence the concentration of this element in the soil. However, analysis of variance revealed 
Table III. Chemical characteristics of the mineral surface horizons of the soils of the Eucalyptus globulus plantations in relation to parent material. Mean values and standard deviations (in parenthesis) are given.

\begin{tabular}{|c|c|c|c|c|}
\hline & Quartzite & Schists & Granites & All \\
\hline Number of plots & 8 & 11 & 25 & 44 \\
\hline Soil depth $(\mathrm{cm})$ & $42.5(14.4)$ & $47.5(23.3)$ & $48.6(10.7)$ & $45.1(22.0)$ \\
\hline Stoniness $(\%)$ & $36(12)$ & $44(21)$ & $40(19)$ & $40(19)$ \\
\hline Water reserve (mm) & $104(33) b$ & $101(70.6) \mathrm{b}$ & $74(40) a$ & $87(52)$ \\
\hline Drought period (days) & 0 & $7(18)$ & $24(24)$ & $16(22)$ \\
\hline $\mathrm{pH}_{\mathrm{H} 2 \mathrm{O}}$ & $4.0(0.5)$ & $4.6(0.4)$ & $4.4(0.3)$ & $4.3(0.4)$ \\
\hline $\mathrm{pH}_{\mathrm{KCl}}$ & $3.1(0.4)$ & $3.7(0.3)$ & $3.7(0.3)$ & $3.8(0.4)$ \\
\hline Organic matter $(\%)$ & $13.6(1.0)$ & $10.9(2.1)$ & $13.9(2.9)$ & $13.2(2.7)$ \\
\hline $\mathrm{N}(\%)^{1}$ & $0.62(0.06)$ & $0.50(0.22)$ & $0.58(0.18)$ & $0.59(0.18)$ \\
\hline $\mathrm{S}(\%)^{1}$ & $0.062(0.029)$ & $0.040(0.028)$ & $0.068(0.053)$ & $0.059(0.045)$ \\
\hline $\mathrm{C}: \mathrm{N}$ & $13.1(1.1)$ & $16.7(14.5)$ & $14.5(5.7)$ & $15.0(8.5)$ \\
\hline $\mathrm{P}\left(\mathrm{mg} \mathrm{kg}^{-1}\right)$ & $8.5(1.8)$ & $6.5(3.0)$ & $4.1(3.8)$ & $5.1(3.8)$ \\
\hline $\mathrm{K}\left(\mathrm{mg} \mathrm{kg}^{-1}\right)$ & $74.4(28.6)$ & $56.0(23.2)$ & $61.9(17.6)$ & $62.8(21.8)$ \\
\hline $\mathrm{Ca}\left(\mathrm{mg} \mathrm{kg}^{-1}\right)$ & $94.0(61.9)$ & $98.3(95.7)$ & $87.3(112.1)$ & $91.7(100.2)$ \\
\hline $\operatorname{Mg}\left(\mathrm{mgkg}^{-1}\right)$ & $52.2(37.3)$ & $18.6(25.9)$ & $21.1(27.9)$ & $23.2(28.9)$ \\
\hline $\operatorname{Mn}\left(\mathrm{mg} \mathrm{kg}^{-1}\right)$ & $0.99(0.43)$ & $10.4(12.2)$ & $10.9(27.0)$ & $11.9(26.0)$ \\
\hline $\mathrm{Fe}\left(\mathrm{mg} \mathrm{kg}^{-1}\right)$ & $330.0(70.7)$ & $188.1(113.5)$ & $216.4(126.2)$ & $210.1(120.3)$ \\
\hline $\mathrm{Cd}\left(\mathrm{mg} \mathrm{kg}^{-1}\right)$ & $0.09(0.07)$ & $0.10(0.03)$ & $0.10(0.05)$ & $0.10(0.0)$ \\
\hline $\mathrm{Cr}\left(\mathrm{mg} \mathrm{kg}^{-1}\right)$ & $1.4(2.8)$ & $1.1(2.7)$ & $1.4(2.4)$ & $1.3(2.4)$ \\
\hline $\mathrm{Cu}\left(\mathrm{mg} \mathrm{kg}^{-1}\right)$ & $0.33(0.32)$ & $0.63(0.35)$ & $0.62(0.66)$ & $0.58(0.6)$ \\
\hline $\mathrm{Ni}\left(\mathrm{mg} \mathrm{kg}^{-1}\right)$ & $0.76(0.29)$ & $0.81(0.16)$ & $0.76(0.34)$ & $0.77(0.3)$ \\
\hline $\mathrm{Pb}\left(\mathrm{mg} \mathrm{kg}^{-1}\right)$ & $5.2(4.1)$ & $3.5(2.4)$ & $3.8(2.4)$ & $3.8(2.6)$ \\
\hline
\end{tabular}

${ }^{1}$ Total amounts (for the remaining elements, available amounts are given).

lower concentrations in the windrowed soils $(P<0.01$, Fig. 1$)$. The levels of extractable $\mathrm{Ca}, \mathrm{Mg}$ and $\mathrm{K}$ were low in all soils, and the soil concentrations of $\mathrm{Ca}$ and $\mathrm{Mg}$ corresponding to the windrowing preparation technique were again significantly lower than those corresponding to the other treatments $(P<$ 0.01 ; Fig. 1).

There were no problems associated with either deficiency or abundance of any of the micronutrients analyzed.

\subsection{Nutritional status of the plantations}

The results of foliar analyses from the plantations under study are shown in Table IV. According to the typical ranges for different eucalypt species given by Judd et al. [33], concentrations of $\mathrm{N}$ and micronutrients were satisfactory in all of the plantations. However, most of the plantations showed low levels of $\mathrm{P}$ and $\mathrm{Ca}$, and some, of $\mathrm{K}$ and $\mathrm{Mg}$. In addition, the levels of $\mathrm{Ca}$ were below the lowest values of the typical ranges. In some plots visible symptoms of $\mathrm{P}$ and $\mathrm{K}$ deficiencies were observed.

No significant differences in the foliar nutrient levels in relation to the different parent materials were revealed by analysis of variance (Tab. IV). Nevertheless, some plots on quartzite showed very low foliar concentrations of $\mathrm{Ca}$ and $\mathrm{Mg}$. The low foliar concentrations of $\mathrm{P}, \mathrm{Ca}, \mathrm{Mg}$ and $\mathrm{K}$ in the plan- tations corresponded with low available levels of these elements in the soils and there were significant relationships between foliar and soil levels of $\mathrm{P}, \mathrm{Ca}, \mathrm{Mn}, \mathrm{Cu}$ and $\mathrm{Ni}$ (Tab. V).

As regards site preparation technique, the windrowed stands showed lower foliar $\mathrm{Ca}$ and $\mathrm{S}$ levels compared with stands in which other site preparation techniques were used (Tab. VI). The ratios of $\mathrm{N}: \mathrm{S}$ and $\mathrm{N}: \mathrm{K}$ also were higher than those in stands in which subsoiling was carried out. There were no significant differences among fertilized and unfertilized stands in relation to foliar concentrations of any of the nutrients.

\subsection{Growth and survival}

The site index (SI) values calculated ranged from 6.3 to $23.1 \mathrm{~m}$. Satisfactory productivities (SI $>21 \mathrm{~m})$, were achieved in only 4 stands and half of the plantations showed SI values lower than 15 , considered as low in a recently published study [23]. The annual increment in DBH (AID) varied between 0.4 and $3.2 \mathrm{~cm}$. Tree mortality ranged from 0 to $19.6 \%$, with an average of $5.9 \%$

Although the average SI, AID and survival were higher in soils developed on schist, no significant differences related to the different parent materials were revealed by analysis of variance. The values of SI and AID, however, differed significantly 
Table IV. Average concentrations $\left(\mathrm{mg} \mathrm{g}^{-1}\right)$ and standard deviations (in parenthesis) of foliar nutrients in the Eucalyptus globulus plantations studied.

\begin{tabular}{lcccc}
\hline & Quartzs & Schists & Granites & All \\
\hline $\mathrm{N}$ & $15.7(1.98)$ & $15.4(2.03)$ & $15.1(3.4)$ & $15.2(2.84)$ \\
$\mathrm{P}$ & $0.63(0.14)$ & $0.56(0.16)$ & $0.58(0.15)$ & $0.58(0.15)$ \\
$\mathrm{S}$ & $1.7(0.31)$ & $1.42(0.44)$ & $1.37(0.30)$ & $1.43(0.35)$ \\
$\mathrm{K}$ & $6.93(2.33)$ & $5.96(1.80)$ & $5.87(1.9)$ & $6.04(1.91)$ \\
$\mathrm{Ca}$ & $2.78(0.69)$ & $3.31(1.75)$ & $3.04(1.68)$ & $3.21(1.77)$ \\
$\mathrm{Mg}$ & $1.24(0.24)$ & $1.72(0.67)$ & $1.73(0.44)$ & $1.66(0.51)$ \\
$\mathrm{Mn}$ & $0.45(0.16)$ & $0.91(0.51)$ & $0.53(0.51)$ & $0.62(0.50)$ \\
$\mathrm{Fe}$ & $0.106(0.03)$ & $0.098(0.051)$ & $0.079(0.013)$ & $0.087(0.031)$ \\
$\mathrm{Cd}$ & $0.003(0.002)$ & $0.008(0.007)$ & $0.008(0.009)$ & $0.008(0.008)$ \\
$\mathrm{Cr}$ & $0.003(0.001)$ & $0.006(0.014)$ & $0.009(0.016)$ & $0.011(0.031)$ \\
$\mathrm{Cu}$ & $0.005(0.003)$ & $0.009(0.003)$ & $0.005(0.002)$ & $0.006(0.003)$ \\
$\mathrm{Ni}$ & $0.062(0.07)$ & $0.072(0.011)$ & $0.064(0.012)$ & $0.066(0.012)$ \\
$\mathrm{Zn}$ & $0.023(0.006)$ & $0.032(0.035)$ & $0.022(0.004)$ & $0.025(0.088)$ \\
$\mathrm{N}: \mathrm{P}$ & $26.5(9.3)$ & $31.1(16.5)$ & $27.4(8.4)$ & $28.2(10.9)$ \\
$\mathrm{N}: \mathrm{K}$ & $2.6(1.2)$ & $2.7(0.7)$ & $3.0(1.7)$ & $2.9(1.4)$ \\
$\mathrm{N}: \mathrm{S}$ & $9.6(2.5)$ & $11.8(3.9)$ & $11.4(2.8)$ & $11.2(3.1)$ \\
$\mathrm{P}: \mathrm{K}$ & $0.11(0.08)$ & $0.10(0.04)$ & $0.11(0.05)$ & $0.11(0.05)$ \\
$\mathrm{Ca}: \mathrm{Mg}$ & $2.33(0.83)$ & $2.12(1.35)$ & $2.01(1.70)$ & $2.16(1.57)$ \\
\hline
\end{tabular}

Table V. Coefficients of correlation for foliar nutrient concentrations and some soil properties.

\begin{tabular}{|c|c|c|c|c|c|c|c|}
\hline & $\mathrm{pH}_{\mathrm{KCl}}$ & $\begin{array}{c}\text { Extract. } \\
\mathrm{P}\end{array}$ & $\begin{array}{c}\text { Extract. } \\
\mathrm{Ca}\end{array}$ & $\begin{array}{c}\text { Extract. } \\
\mathrm{Mg}\end{array}$ & $\begin{array}{c}\text { Extract. } \\
\mathrm{Mn}\end{array}$ & $\begin{array}{c}\text { Extract. } \\
\mathrm{Cu}\end{array}$ & $\begin{array}{c}\text { Extract. } \\
\mathrm{Ni}\end{array}$ \\
\hline Foliar N & $-0.33^{*}$ & & & & & & \\
\hline Foliar P & & $0.38 *$ & & & & & \\
\hline Foliar Ca & & & $0.39 *$ & $0.34 *$ & & & \\
\hline \multicolumn{8}{|l|}{ Foliar Mg } \\
\hline Foliar K & $-0.48 * *$ & & & & & & \\
\hline Foliar Mn & $0.43^{* *}$ & & & & $0.61 * *$ & & \\
\hline Foliar $\mathrm{Cu}$ & & & & & & $0.31 *$ & \\
\hline Foliar Ni & & & & & & & $0.39 *$ \\
\hline
\end{tabular}

* Significant at $P<0.05$; ** significant at $P<0.01$.

according to the site preparation technique (Tab. VII). Thus, these growth indices were lowest in the plantations where logging residues were removed $(P<0.05)$. There were significant relationships between the percentage of dead plants and both the length of the drought period and foliar levels of $\mathrm{P}$ and $\mathrm{Mg}$ (Tab. VIII). Plantation productivity correlated negatively with altitude, the length of the drought period and soil $\mathrm{C}: \mathrm{N}$ ratio, but positively with some soil parameters ( $\mathrm{pH}$ and available $\mathrm{Ca}$ and $\mathrm{P}$ ) and foliar $\mathrm{Ca}$ concentration (Tab. VIII). In addition, the plantations showing least growth $(\mathrm{SI}<10)$ were those in which there was a significantly $(P<0.05)$ longer drought period (> 30 days), lower foliar $\mathrm{Ca}\left(<3 \mathrm{mg} \mathrm{g}^{-1}\right)$, higher $\mathrm{C}: \mathrm{N}$ ratio $(>15)$ and low levels of soil available $\mathrm{P}\left(<3 \mathrm{mg} \mathrm{kg}^{-1}\right)$, $\mathrm{Ca}\left(<3 \mathrm{mg} \mathrm{kg}^{-1}\right)$ and $\mathrm{Mg}\left(<10 \mathrm{mg} \mathrm{kg}^{-1}\right)$.
Table VI. Foliar concentrations of some elements in Eucalyptus globulus plantations in relation to the site preparation technique. Significantly different means are indicated by different letters, a > $\mathrm{b}>\mathrm{c}(P<0.05)$.

\begin{tabular}{lcccc}
\hline$\left(\mathrm{mg} \mathrm{g}^{-1}\right)$ & Pitting & Windrowing & Subsoiling & Terracing \\
\hline $\mathrm{N}$ & $13.9(2.4)$ & $14.8(3.3)$ & $15.2(1.7)$ & $16.7(4.0)$ \\
$\mathrm{S}$ & $1.39(0.15) \mathrm{a}$ & $1.16(0.24) \mathrm{b}$ & $1.61(0.38) \mathrm{a}$ & $1.47(0.23) \mathrm{a}$ \\
$\mathrm{P}$ & $0.63(0.07)$ & $0.57(0.17)$ & $0.61(0.15)$ & $0.57(0.14)$ \\
$\mathrm{K}$ & $6.5(2.3)$ & $5.8(0.8)$ & $7.2(1.5)$ & $5.5(2.5)$ \\
$\mathrm{Ca}$ & $4.1(1.6) \mathrm{a}$ & $2.3(1.3) \mathrm{b}$ & $4.0(2.1) \mathrm{a}$ & $3.8(0.83) \mathrm{a}$ \\
$\mathrm{Mg}$ & $1.3(0.5)$ & $1.9(0.4)$ & $1.6(0.4)$ & $1.6(0.8)$ \\
$\mathrm{Mn}$ & $1.0(0.96)$ & $0.51(0.36)$ & $0.76(0.53)$ & $0.38(0.30)$ \\
$\mathrm{Fe}$ & $0.071(0.011)$ & $0.079(0.014)$ & $0.094(0.041)$ & $0.094(0.029)$ \\
$\mathrm{N}: \mathrm{P}$ & $22.3(4.8)$ & $28.1(10.1)$ & $28.7(13.3)$ & $30.0(8.8)$ \\
$\mathrm{N}: \mathrm{S}$ & $10.1(2.4) \mathrm{ab}$ & $12.9(2.7) \mathrm{a}$ & $10.0(3.0) \mathrm{b}$ & $11.6(3.0) \mathrm{ab}$ \\
$\mathrm{N}: \mathrm{K}$ & $2.2(0.4) \mathrm{ab}$ & $3.0(1.6) \mathrm{a}$ & $2.4(0.6) \mathrm{b}$ & $4.1(2.06) \mathrm{ab}$ \\
$\mathrm{Ca}: \mathrm{Mg}$ & $3.9(2.8)$ & $1.2(0.5)$ & $2.7(1.6)$ & $1.8(0.9)$ \\
\hline
\end{tabular}

Table VII. Productivity indices and tree mortality in the eucalypt plantations studied, in relation to the site preparation technique used. Significantly different means are indicated by different letters, $a>$ $\mathrm{b}>\mathrm{c}(P<0.05)$.

\begin{tabular}{lcccc}
\hline Site preparation & No. plots & $\begin{array}{c}\text { SI } \\
(\mathrm{m})\end{array}$ & $\begin{array}{c}\text { AID } \\
\left(\mathrm{cm} \mathrm{year}^{-1}\right)\end{array}$ & $\begin{array}{c}\text { Mortality } \\
(\%)\end{array}$ \\
\hline Pitting & 4 & $20.58 \mathrm{a}$ & $1.71 \mathrm{a}$ & $4.77 \mathrm{a}$ \\
Windrowing & 13 & $12.67 \mathrm{c}$ & $0.91 \mathrm{~b}$ & $5.50 \mathrm{a}$ \\
Subsoiling & 19 & $16.31 \mathrm{~b}$ & $1.55 \mathrm{a}$ & $5.58 \mathrm{a}$ \\
Terracing & 8 & $14.76 \mathrm{bc}$ & $1.45 \mathrm{a}$ & $8.61 \mathrm{a}$ \\
\hline
\end{tabular}

SI, site index. AID, annual increment in DBH.

The drought period, altitude and soil available $\mathrm{Ca}$ accounted for up to $30 \%$ of the variation in SI and AID (Eqs. (1)-(2), Tab. IX). On the basis of nutrient concentrations in leaves, the simple linear regression equations with with foliar $\mathrm{Ca}$ accounted for 40 and $27 \%$ of the variation of SI and AID, respectively (Eqs. (3)-(4), Tab. IX). The combination of drought period and foliar Ca levels accounted for $43-47 \%$ of the productivity (Eqs. (5)-(6), Tab. IX).

\section{DISCUSSION}

\subsection{Soil fertility and nutritional status}

Foliar analyses in this study revealed lower concentrations of $\mathrm{P}, \mathrm{Ca}, \mathrm{Mg}$ and $\mathrm{K}$ than those reported for Eucalyptus globulus plantations in southern Spain [25] and central Portugal [47], growing on more fertile soils. Such low levels of these nutrients are common in acid soils with low eCEC $[15,56]$. In contrast, foliar $\mathrm{N}$ concentrations were higher than in these other regions. The adequate foliar levels of $\mathrm{N}$ can be explained by the high total $\mathrm{N}$ contents in the soils and $\mathrm{C}: \mathrm{N}$ ratios that favour mineralization of this element. In addition, the high acidity of the soils favours the presence of $\mathrm{NH}_{4}^{+}$, which eucalypts assimilate in preference to $\mathrm{NO}_{3}^{-}[1]$. 
Table VIII. Coefficients of correlation for productivity indices, foliar nutrient concentrations and some soil properties.

\begin{tabular}{lccc}
\hline & SI & AID & Mortality \\
\hline Altitude & $-0.39^{*}$ & & \\
Drought period & $-0.40^{* *}$ & $-0.46^{* *}$ & $0.33^{*}$ \\
Stocking & & $-0.44^{* *}$ & \\
Foliar Ca & $0.52^{* *}$ & $0.63^{* *}$ & \\
Foliar P & & & $-0.31^{*}$ \\
Foliar $\mathrm{Mg}$ & & & $-0.32^{*}$ \\
Foliar N/P & & & $0.46^{* *}$ \\
Foliar Ca/Mg & $0.57^{* *}$ & $0.63^{* *}$ & \\
Soil pH $\mathrm{KCl}$ & & $0.33^{*}$ & \\
Soil C:N & $-0.32^{*}$ & $-0.38^{*}$ & \\
Available Ca $\left(\mathrm{mg} \mathrm{kg}^{-1}\right)$ & $0.31^{*}$ & $0.43^{* *}$ & \\
Available $\mathrm{P}\left(\mathrm{kg} \mathrm{ha}^{-1}\right)$ & & $0.31^{*}$ & \\
\hline
\end{tabular}

* Significant at $P<0.05$; ** significant at $P<0.01$.

Cromer [12] and Prado and Toro [48] suggested optimum values of between 13 and 15 for the N:P ratio, much lower than those found in the plantations under study here (Tab. IV), reflecting that $\mathrm{P}$ indeed is a growth limiting element. Other ratios used in nutritional studies of eucalypts are $\mathrm{N}: \mathrm{K}, \mathrm{K}: \mathrm{P}$ and $\mathrm{Ca}: \mathrm{Mg}$. Foliar $\mathrm{N}: \mathrm{K}$ ratios were lower than the reference values given by Herbert [29] for E. grandis (3.5) and by Prado and Toro [48] for Eucalyptus globulus (3.9). The K:P ratios were much higher than the average levels of 5, reported by Herbert [29] and Judd et al. [33]. In most of the plantations, the $\mathrm{Ca}: \mathrm{Mg}$ ratio was lower than the reference value of 3.3 proposed as optimum by Herbert [29]. Considering these results, $\mathrm{Ca}$ and $\mathrm{P}$ appear to be the nutrients that limit growth under the conditions in the study area.

Phosphorus deficiency is the most common nutrient deficiency in Eucalyptus spp. growing on sandy- or loamy-textured acidic soils with a high capacity for fixing P [2]. Experiments in which NPK fertilizer was applied at plantation establishment revealed increases in productivity and in foliar $P$ during the two years following fertilization $[6,20,26]$.

The concentrations of all of the micronutrients analyzed were satisfactory, confirming that deficiencies of trace elements are not common in eucalypts, although deficiencies of
$\mathrm{Fe}, \mathrm{Cu}[12]$ or B ([11], the latter element was not included in this study) have been reported.

Significant relationships between nutrient concentrations in leaves and topsoil properties $(\mathrm{pH}$, extractable macro- and micronutrients) were found for only some nutrients. Poor correlations between these parameters are frequently found in eucalypt plantations beyond 2 years of age [2] and are attributed to the dilution of nutrients as the trees increase in size. Indeed, the foliar levels of nutrients were not influenced by the type of parent material. This is probably because bioavailability of nutrients to eucalypts is not directly reflected by the soil parameters investigated in this study, but also depends on the activities of microorganisms and mycorrhizae.

One important finding was the low foliar levels of nutrients, even in plantations that were fertilized at establishment. Similar responses have been reported by other researchers, who have discussed the short-lived effect of this type of fertilization $[12,34,44]$. Factorial design experiments previously carried out in the study region have shown that, in these $\mathrm{N}$ enriched soils, $\mathrm{P}$ fertilization improved both the foliar levels of this element and growth $[6,20,26]$. However, the increase in foliar P lasted for 2 years, which is consistent with observations made in other areas and for which various explanations have been given: a) that the root system occupied a large volume of a soil that had not been fertilized with $\mathrm{P}[15], \mathrm{b})$ the fixation of $\mathrm{P}$ by the soil and/or c) the dilution effect resulting from the increase in thickness and the surface area of the leaves $[12,27,46]$.

The most common method of fertilization carried out in NW Spain, as well as in other parts of the world [53], consists of a single application of NPK type fertilizer at establishment. The dose usually used is approximately $100 \mathrm{~g}$ of NPK type fertilizer per plant, i.e. $10-20 \mathrm{~kg} \mathrm{~N}^{-1}, 8-14 \mathrm{~kg} \mathrm{P} \mathrm{ha}^{-1}$ and 8$10 \mathrm{~kg} \mathrm{~K} \mathrm{ha}^{-1}$, which is clearly insufficient to compensate the removal of nutrient during harvesting [9]. In countries such as e.g. Australia, New Zealand and Brazil, similar findings have led to repeated applications of fertilizer containing higher levels of nutrients (sometimes combined with thinning), with satisfactory results (e.g. [8, 15, 33, 35]).

A major factor influencing the nutrient status was the technique of site preparation used. Removal of the logging residues and the humus layer reduced soil available levels of $\mathrm{P}, \mathrm{Ca}$ and $\mathrm{Mg}$ and foliar $\mathrm{Ca}$. Different studies carried out in the study

Table IX. Multiple regressions for growth parameters, soil properties and foliar nutrient concentrations.

\begin{tabular}{|c|c|c|c|}
\hline Regression equation & Eq. & $\mathrm{R}^{2}$ & SEE \\
\hline \multicolumn{4}{|l|}{ Soil properties } \\
\hline SI $=20.63-0.0669 \cdot$ Drought period $-0.0107 \cdot$ Altitude & (1) & 0.30 & 0.50 \\
\hline $\mathrm{AID}=1.358+0.001497 \cdot$ Soil Ca-0.00814 $\cdot$ Drought period & $(2)$ & 0.30 & 3.44 \\
\hline \multicolumn{4}{|l|}{ Foliar nutrient concentrations } \\
\hline $\mathrm{SI}=11.693+1.177 \cdot$ Foliar $\mathrm{Ca}$ & (3) & 0.39 & 0.46 \\
\hline $\mathrm{AID}=0.727+0.2061 \cdot$ Foliar $\mathrm{Ca}$ & (4) & 0.27 & 3.44 \\
\hline \multicolumn{4}{|l|}{ Site properties and foliar nutrient concentrations } \\
\hline $\mathrm{SI}=16.83+0.886 \cdot$ Foliar $\mathrm{Ca}-0.0465 \cdot$ Drought period & $(5)$ & 0.47 & 0.43 \\
\hline AID $=0.943+0.177 \cdot$ Foliar Ca $-0.0076 \cdot$ Drought period & $(6)$ & 0.43 & 3.13 \\
\hline
\end{tabular}

SEE, Standard Error Estimate. 
region [9] and elsewhere [30, 56], have shown that bark and leaves are especially rich in macronutrients. The amounts of nutrients normally removed by this operation are estimated as $4.6 \mathrm{~kg} \mathrm{P} \mathrm{ha}^{-1}, 56.5 \mathrm{~kg} \mathrm{~K} \mathrm{ha}^{-1}, 82.5 \mathrm{~kg} \mathrm{Ca} \mathrm{ha}^{-1}$ and $531 \mathrm{~kg}$ of total $\mathrm{N} \mathrm{ha}^{-1}$, assuming that the front blade removes $10 \mathrm{~cm}$ of the humus layer and without considering the presence of logging residues. This effect may be reflected by the lower concentrations of available $\mathrm{Ca}$ and higher $\mathrm{C} / \mathrm{N}$ ratios in the windrowed soils. These results are consistent with those reported in previous studies carried out in Portugal [38] and northern Spain [43].

\subsection{Growth and mortality}

Growth in diameter was affected by stocking density early on in development and as crown competition did not yet exist in the plantations, there may have been more intense competition at the roots. Such early diameter depletion has also been reported in spacing trials $[54,55]$. This finding indicates that the initial stocking of some plantations (> 1500 stems ha $\left.^{-1}\right)$ may be excessive where the silvicultural management includes short rotations with no thinning.

The levels of growth recorded in the present study were lower than those reported for a continuous forest inventory of stands in Galicia, carried out during the past 20-30 years (mainly in coppices; [23]). They are also lower than those reported for plantations of the same species in dry regions in central Portugal $[47,55]$, indicating that these new plantations have been established in areas with severe limitations for growing this species.

The results of this study indicate that the main factors affecting stand development of the eucalypt plantations are altitude, length of drought period and soil and foliar levels of $\mathrm{Ca}$. These findings are consistent with those of other studies carried out in Australia [12] and Portugal [19] in which it was shown that tree growth is mainly limited by the availability of water, with nutrient availability being an additional factor. In the present study, the unsatisfactory productivity of the plantations can therefore be explained by poor site quality, determined by infertile soils and relatively high altitudes (the latter probably because of lower temperatures). Thus, $25 \%$ of the plots were in newly established afforestations above the altitude recommended for this species in the region $(0-500 \mathrm{~m})$ [55], and $11 \%$ of the soils had a water reserve lower than $50 \mathrm{~mm}$.

Furthermore, windrowing had a negative effect on soil properties and therefore on forest productivity (height and diameter growth). The results of the present study indicated subsoiling to be the most suitable site preparation technique for eucalypt plantations, in agreement with the results reported by Florence [22] and Ruiz et al. [50]. Analysis of the data did not reveal lower productivity in shallow soils. Preparation of the site by subsoiling may improve development of the root system and partially compensate the shallowness of the soils, at least during the first years following plantation establishment. However, it is also possible that limitations caused by shallow soils may be manifested at a later date, when the root system is more fully developed, as occurs in adult stands of Pinus pinaster [5] and of Pinus radiata [51] in the region. Nevertheless, one indirect influence of soil depth was the lower productivity in the soils subjected to longer drought periods, which was determined mainly by soil depth, stoniness and rainfall deficit.

Our results indicate that the information gained from soil and foliar analyses is of limited use in predicting the productivity of these plantations. The poor correlations between productivity and nutrient concentrations in soils and leaves are consistent with the results reported for other young eucalypt plantations (e.g. [13, 33, 35]). These studies have shown that Eucalyptus spp. make efficient use of available nutrients for rapid growth, sometimes leading to dilution of the nutrients in tissues. This makes it difficult to establish the critical levels of nutrients in leaves, below which growth is reduced [44].

In spite of the low foliar P concentrations, productivity was not significantly correlated with the concentrations of this element in soils or leaves. The lack of a relationship was probably due to the narrow range of this element in these soils $(0.1-$ $\left.16.1 \mathrm{mg} \mathrm{kg}^{-1}\right)$ and leaves $\left(0.21-0.88 \mathrm{mg} \mathrm{g}^{-1}\right)$. According to McLaughlin [41], soil extractable P may not be a good indicator of productivity because most of the $\mathrm{P}$ taken up by trees during a forest rotation is derived from soil nutrient turnover through mineralization of organic P. Nevertheless, net immobilization of this element can occur during decomposition in the stands due to the low P concentration in the soil [45].

\section{CONCLUSIONS}

The differences in productivities in the plantations under study can be attributed to altitude, the length of drought period and also to nutritional constraints. The data obtained indicates the need for carrying out better site selection and for improving silviculture management in newly established plantations. Because of their effect on the nutrient and water regimes, it is important to retain logging residues, particularly in reforested plantations growing on shallow soils at risk of erosion. It appears that the fertilization regimes presently used in eucalypt plantations may be adequate for the first years following establishment, but are not sufficient for later development. Repeated applications of fertilizer containing higher levels of nutrients should be tested.

Acknowledgements: We thank Mr. Federico Sánchez-Rodríguez, Mr. Fernando Solla and Mr Christophe Orazio for their valuable comments and Mrs. Maria Fé López and Mrs. Placeres Conde for their assistance in the laboratory. The present study was carried out as part of a project financed by the Xunta de Galicia and Asociación Galega Monte-Industria. The forestry companies which collaborated in the study were Boibel, Ecar and Norfor. We also thank two anonymous referees for their positive and valuable suggestions.

\section{REFERENCES}

[1] Adams M.A., Attiwill P.M., Nitrate reductase activity and growth response of forest species to ammonium and nitrate sources of nitrogen, Plant Soil 66 (1982) 373-381.

[2] Attiwill P.M., Adams M.E., Nutrition of Eucalypts, CSIRO Publishing, Collingwood, Australia, 1996.

[3] Bailey R.L., Clutter J.L., Base-age invariant polymorphic site index curves, For. Sci. 20 (1974) 155-159. 
[4] Bará S., Fertilización forestal. Consellería de Agricultura, Gandería e Montes, Xunta de Galicia, 1990.

[5] Bará S., Toval G., Calidad de estación del Pinus pinaster Ait. en Galicia. Comunicaciones INIA. Serie Recursos Naturales 24, Madrid, 1983.

[6] Basurco F., Noriega M., Romeral L., Toval G., Ensayos de fertilización localizada en masas clonales de Eucalyptus globulus en el momento de la plantación en la provincia de A Coruña, in: III Congreso Forestal Español, mesa 3, 2001, pp. 671-675.

[7] Bermúdez Alvite J., Touza M., Las cifras del tercer inventario forestal en Galicia y su incidencia en la industria de transformación de la madera, CIS-Madera 4 (2000) 6-24.

[8] Birk E.M., Turner J., Response of flooded gum (Eucalyptus grandis) to intensive cultural treatments: biomass and nutrient content of eucalypt plantations and native forests, For. Ecol. Manage. 47 (1992) 1-28.

[9] Brañas J., González-Río F., Merino A., Contenido de nutrientes en biomasa vegetal y suelos de plantaciones de Eucalyptus globulus en el norte de Galicia, Investig. Agrar. Sist. Recur. For. 9 (2000) 317 335.

[10] Calvo de Anta R., El Eucalipto en Galicia. Sus Relaciones con el Medio Natural, Universidad de Santiago de Compostela, La Coruña, 1992

[11] Coutinho J., Bento J., Vale R., Rafael J., Efeito do boro em Eucalyptus globulus no norte e centro interiores de Portugal, in: Actas do III Congreso Florestal Nacional, Figueira da Foz, 1993, pp. 364-372.

[12] Cromer R.N., Silviculture of eucalypt plantations in Australia, in: Attiwill P.M., Adams M.A. (Eds.), Nutrition of Eucalypts, CSIRO Publishing, Collingwood, Australia, 1996, pp. 259-274.

[13] Cromer R.N., Williams E.R., Biomass and nutrient accumulation in a planted E. globulus (Labill.) fertilizer trial, Aust. J. Bot. 30 (1982) 265-278.

[14] Dambrine E., Vega J.A., Taboada T., Rodríguez L., Fernández C., Macías F., Grass J.M., Bilans d'éléments minéraux dans de petits bassins versants forestiers de Galice (NW Espagne), Ann. For. Sci. 57 (2000) 23-38.

[15] De Barros N.F., De Novais R.F., Eucalypt nutrition and fertilizer regimes in Brazil, in: Attiwill P.M., Adams M.A. (Eds.), Nutrition of Eucalypts, CSIRO Publishing, Collingwood, Australia, 1996, pp. 335-355.

[16] D.G.C.N., Tercer Inventario Forestal Nacional 1997-2006: Galicia, Ministerio de Medio Ambiente, Dirección General de Conservación de la Naturaleza, Madrid, 2000.

[17] Díaz Fierros F., Gil Sotres F., Capacidad Productiva de los Suelos de Galicia, Universidad de Santiago de Compostela, 1984.

[18] Español E., Zás R., Vega G., Contenidos foliares en macro y micronutrientes en nueve especies de eucaliptos en el noroeste español, Investig. Agrar. Sist. Recur. For. 9 (2000) 209-217.

[19] Fabião A., Madeira M., Steen E., Kätterer T., Ribeiro C., Araújo C., Development of root biomass in an Eucalyptus globulus plantation under different water and nutrient regimes, Plant Soil 168-169 (1995) 215-233.

[20] Fernández A., González-Río F., Merino, A., Efectos de la Fertilización sobre las Concentraciones Foliares de Nutrientes en Eucalyptus globulus, Memoria de la Universidad de Santiago de Compostela para CEASA, Unpublished report, 1997.

[21] Fernández A., Evaluación de la Producción y Productividad del Monte bajo Eucalipto, Publicaciones del Centro Forestal de Lourizán, Pontevedra, 1982.

[22] Florence R.G., Ecology and Silviculture of Eucalypt Forest, CSIRO, Australia, 1996.

[23] García O., Ruíz F., A growth model for eucalypt in Galicia, Spain, For. Ecol. Manage. 173 (2003) 49-62.

[24] García-Rodeja I., Gil-Sotres F., Prediction of parameters describing phophorus-desorption kinetics in soils of Galicia (NW Spain), J. Environ. Qual. 26 (1997) 1363-1369.

[25] González Esparcia E., Penalva Rodríguez F., Gómez Altamiro C., Exigencias nutritivas del Eucalyptus globulus en el suroeste español comparadas con las de otras especies, Anales del INIA 9 (1985) 63-74.
[26] González-Río F., López J., Astorga R., Castellanos A., Fernández O., Gómez C., Fertilización y control de la vegetación accesoria en plantaciones de eucalipto, Comunicaciones II Congreso Forestal Español 3, 1997, pp. 271-276.

[27] Grove T.S., Twig and foliar nutrient concentration in relation to nitrogen and phosphorus supply in a eucalypt (Eucalyptus diversicolor F. Muell.) and an understorey legume (Bossiaea laidlawiana Tovey and Morris), Plant Soil 126 (1990) 265-275.

[28] Guitián Ojea F., Suelos de la Provincia de Lugo, Instituto de Investigaciones Agrobiológicas de Galicia, Santiago de Compostela, 1982.

[29] Herbert M.A., Fertilizers and eucalypt plantations in South Africa, in: Attiwill P.M., Adams M.A. (Eds.), Nutrition of Eucalypts, CSIRO Publishing, Collingwood, Australia, 1996, pp. 303-325.

[30] Hopmans P., Stewart H.T.L., Flinn D.W., Impacts of harvesting on nutrients in an eucalypt ecosystem in southeastern Australia, For. Ecol. Manage. 59 (1993) 29-51.

[31] Jones H.E., Madeira M., Herráez L., Dighton J., Fabiao A., González-Río F., Fernández Marcos M., Gómez C., Tomé M., Feith H., Howson G., The effect of organic matter management methods on the productivity of Eucalyptus globulus stands in Spain and Portugal: tree production and litter decomposition in relation to site and treatment, For. Ecol. Manage. 122 (1999) 73-86.

[32] Jones J.B., Wolf B., Mills H.A., Plant Analysis Handbook, MicroMacro Publishing, Georgia, USA, 1991.

[33] Judd T.S., Attiwill P.M., Adams M.A., Nutrient concentrations in Eucalyptus: A synthesis in relation to differences between taxa, sites and components, in: Attiwill P.M., Adams M.A. (Eds.), Nutrition of Eucalypts, CSIRO Publishing, Collingwood, Australia, 1996, pp. 123-153.

[34] Judd T.S., Bennett L.T., Weston C.J., Attiwill P.M., Whiteman P.H., The response of growth and foliar nutrients to fertilizers in young Eucalypts globulus (Labill.) plantations in Gippsland, southeastern Australia, For. Ecol. Manage. 82 (1996) 87-101.

[35] Knight P.J., Nicholas I.D., Eucalypt nutrition: New Zealand experience, in: Attiwill P.M., Adams M.A. (Eds.), Nutrition of Eucalypts, CSIRO Publishing, Collingwood, Australia, 1996, pp. 275-302.

[36] Macías F., Calvo R., Suelos de la Provincia de La Coruña, Diputación Provincial de La Coruña, 1992.

[37] Macías F., Chesworth W., Weathering in humid regions, with emphasis on igneous rocks and their metamorphic equivalents, in: Martini L., Chesworth W. (Eds.), Weathering, Soils and Paleosols, Elsevier, Amsterdam, 1992, pp. 283-306.

[38] Madeira M., Melo M.G., Alexandre C.A., Steen E., Effect of deep ploughing and superficial disc-harrowing on physical and chemical soil properties and biomass in a new plantation of E. globulus, Soil Tillage Res. 14 (1989) 163-175.

[39] Mansilla Vázquez J.P., Pérez Otero R., El defoliador del eucalipto Gonipterus scutellanus, Phytoma-España, 1989, pp. 36-42.

[40] Martínez Cortizas A., La reserva de agua útil de los suelos de Galicia. I. Relación con la textura y el contenido de materia orgánica, Ann. Edafol. Agrobiol. 47 (1988) 561-572.

[41] McLaughlin M.J., Phosphorus in Australian forest soils, in: Attiwill P.M., Adams M.A. (Eds.), Nutrition of Eucalypts, CSIRO Publishing, Collingwood, Australia, 1996, pp. 1-30.

[42] Mehlich A., Mehlich $\mathrm{N}^{\circ} 3$ extractant: a modification of Mehlich No 2 extractant, Commun. Soil Sci. Plant Anal. 15 (1984) 1409-1416.

[43] Merino A., Edeso J.M., Soil fertility rehabilitation in young Pinus radiata $\mathrm{D}$. Don. plantations from northern Spain after intensive site preparation, For. Ecol. Manage. 116 (1999) 83-91.

[44] Olsen J.K., Bell L.C., A glasshouse evaluation of "critical" N and P concentrations and N:P ratios in various plant parts of six eucalypt species, Aust. J. Bot. 38 (1990) 281-298.

[45] Palm C.A., Myers R.J.K., Nandwa S.M., Combined use of organic and inorganic nutrient stores for soil fertility maintenance and replenishment, in: Buresh R.J., Sánchez P.A., Calhoum F.G. (Eds.), SSSA Special Publication, Number 51. Soil Science Society of America and American Society of Agronomy, Madison, Wisconsin, USA, 1997, pp. 193-217. 
[46] Pereira J.S., Linder S., Araújo M.C., Pereira H., Ericsson T., Borralho N., Leal C., Optimization of biomass production in Eucalyptus globulus plantations. A case study, in: Pereira J.S., Landsberg J.J. (Eds.), Biomass Production by Fast-Growing Trees, Kluwer Academic Publisher, Dordrecht, 1989, pp. 101-121.

[47] Pereira J.S., Tomé M., Madeira M., Oliveira A.C., Tomé J., Almeida M.H., Eucalypt plantations in Portugal, in: Attiwill P.M., Adams M.A. (Eds.), Nutrition of Eucalypts, CSIRO Publishing, Collingwood, Australia, 1996, pp. 371-387.

[48] Prado J.A., Toro, J.A., Silviculture of eucalypt plantations in Chile, in: Attiwill P.M., Adams M.A. (Eds.), Nutrition of Eucalypts, CSIRO Publishing, Collingwood, Australia, 1996, pp. 357-370.

[49] Rubio B., Gil-Sotres F., Distribution of four major forms of potassium in soils of Galicia (N. W. Spain), Commun. Sci. Plant Anal. 28 (1997) 1805-1816.

[50] Ruíz F., Soria F., Toval G., Ensayos de preparación del terreno para el establecimiento de masas clonales de Eucalyptus globulus
(Labill.) en distintos suelos de la provincia de Huelva, III Congreso Forestal Español, mesa 3, 2001, pp. 117-124.

[51] Sánchez-Rodríguez F., López C., Rodríguez-Soalleiro R., Español E., Merino A., Influence of edaphic factors on the productivity of Pinus radiata D. Don plantations in NW Spain, For. Ecol. Manage. 181 (2002) 171-189.

[52] SAS Institute Inc., SAS/STAT User's guide, Version 6, Volume 2 , Cary, NC (1990).

[53] Schönau A.P.G., Herbert M.A., Fertilizing eucalypts at plantation establishment, For. Ecol. Manage. 29 (1989) 221-244.

[54] Soares P., Tomé M., A tree crown ratio prediction equation for eucalypts plantations, Ann. For. Sci. 58 (2001) 193-202.

[55] Soares P., Tomé M., Height-diameter equation for first rotation eucalypt plantations in Portugal, For. Ecol. Manage. 166 (2002) 99-109.

[56] Spangenberg A., Grimm U., Sepeda da Silva J.R., Fölster H., Nutrient store export rates of Eucalyptus urograndis plantations in eastern Amazonia (Jari), For. Ecol. Manage. 80 (1996) 225-234. 